\title{
APPRAISAL OF THE PHILOSOPHICAL, POLITICAL AND IDEOLOGICAL CONCEPT OF PRIVATIZATION: A REFLECTION ON THE NIGERIA EXPERIENCE
}

\author{
M. C. Ogwezzy, S. A. Bello
}

\author{
Michael C. Ogwezzy \\ LL.B, (Ibadan) B.L, LL.M, (Nigeria) ML.D, (DELSU) MASIO/LL.M, (ZH/Switzerland) \\ (Ph.D in View), Lecturer I, \\ Lead City University, Nigeria \\ *Correspondence: Lead City University, Off Lagos-Ibadan Expressway, Toll Gate Area, \\ Ibadan, Oyo State-Nigeria, \\ E-mail: ogwezzym@yahoo.com

\section{Shittu A. Bello} \\ LL.B, (ABU) B.L, LL.M (Ife), Ph.D (Ilorin) Senior Lecturer, \\ Lead City University, Nigeria \\ *Correspondence: Lead City University, Off Lagos-Ibadan Expressway, Toll Gate Area, \\ Ibadan, Oyo State-Nigeria, \\ E-mail: shittuabello@gmail.com
}

\begin{abstract}
The concept of privatization is not a new phenomenon but the practice continues to elicit novel ideas that attract comments from academics and other practitioners around the globe. It is an idea that have transcended over the decades to ensure that public enterprises are better managed by private individuals and organizations in order to achieve efficiency in their productivity. Our primary goal in this article to examine the philosophical, political and ideological basis of the concept of privatization and how this idea has found its relevance in Nigerian Political landscape via a reflecting on the Nigerian experience. This paper will start by examining the universal ideas behind concept of privatization, the meaning and origin of privatization, its influence on Nigeria and references will be drawn from other countries around the world that have made some giant strides in the field of privatisation of their State owned enterprises. There will be an overview of the methods of privatization, the nature and pattern of privatization in Nigeria and why the government opted for privatization of public utilities. This paper will end with the authors' conclusion on how Nigeria can benefit from privatisation policy.
\end{abstract}

Keywords: privatization, Nigeria, politics, private sector

\section{Introduction}

Privatisation is a concept that has found its relevance in different fields of human endeavour namely Political Science, Economics, Government, Sociology, Law among others. It is a concept of many ideology ${ }^{1}$ the ideas about privatization dates from Ancient Greece, when governments contracted out almost everything to the private sector. In the Roman Republic private individuals and companies performed the majority of services including tax collection

\footnotetext{
1 See generally: Bulent Seven, "Legal Aspects of Privatisation: A Comparative Study of European: Implementations", Dissertation.com 2001, available online at www.dissertation.com/library/112174a.htm, accessed 12 June, 2013.
} 
(tax farming), army supplies (military contractors), religious sacrifices and construction. However, the Roman Empire also created state-owned enterprises, for example, much of the grain was eventually produced on estates owned by the Emperor. Some scholars suggest that the cost of bureaucracy was one of the reasons for the fall of the Roman Empire. ${ }^{2}$ Perhaps one of the first ideological movements towards privatization came during China's golden age of the Han Dynasty. Taoism came into prominence for the first time at a state level, and it advocated the laissez-faire principle of $W u$ we, which literally means "do nothing". 3

It could easily be recalled that for most part of the twentieth century, there were two opposing ideologies on how society should be governed and developed: capitalism versus socialism. Capitalist ideology typified by neo-liberalism insists that a self-regulated system of market will bring about a spontaneous process of development. On the other hand, the Socialists and many other variants such as the interventionists argue that unregulated capitalism will always bring about poverty, unemployment and human misery and there is the need to intervene to regulate the market. At the end of the $20^{\text {th }}$ century with the end of the cold war, there is an ascendancy of capitalism and neo-liberalism ${ }^{4}$ and this phenomenon has been a necessary concomitant to the principle of privatisation, which involves the transfer of control in terms of ownership and management from the government to private investors. This phenomenon has gained worldwide support and frenzy. Following the privatisation of British Telecom in 1984 under the Telecommunications Act, and the host of the other privatisations that took place in Britain thereafter, several nations particularly those in Africa, have come to embrace the principle as a way of eliminating low performance and inefficiency in the public enterprises sector ${ }^{5}$. Though it was argued that Privatisation as a tool for economic management came to the front burner when Chile became the first country to turn public assets/businesses to private operators in the early 1970s. Since then, over 140 countries (both developed and developing) have embraced privatisation as a route to economic growth and prosperity. ${ }^{6}$

2. Definitions of the term 'Privatisation'

The term "privatization" can have different meanings depending on the starting point and approach in the definition. The starting point will vary depending upon the scope, range or structure of privatization. Since each country has different social, political and economic differences and circumstances, the definition and even the understanding of the concept of privatization may vary. ${ }^{7}$ However, in a wider sense, privatisation can be defined as policies designed to improve the operating efficiency of public-sector enterprises through increased exposure to competitive market forces. Privatization, in nutshell, is a term of art which may best be described as that component of the government's strategy to restructure the economy by relinquishing fully or partially its ownership of some corporations, parastatals and public owned companies through sale of its equity shares or ownership of these organisation to private

\footnotetext{
${ }^{2}$ David Parker and David S. Saal, International Handbook on Privatization, Edward Elgar Publishing, 2003.

3 "History of Privatization", available online at http://en.wikipedia.org/wiki/Privatization", accessed 20 June, 2013.

${ }^{4}$ Otive Igbuzor, Privatisation In Nigeria: Critical issues of concern to civil society, A Paper Presented At A Power Mapping Roundtable Discussion On The Privatisation Programme In Nigeria Organised By SocioEconomic Rights Initiative (Seri) held at Niger Links Hotel Abuja on 3rd September, 2003.

${ }^{5}$ N. L. Dimgba, "Privatisation in Nigeria: Guidelines for the Foreign Investor", at p. 2, available online at, http://www.chrisogunbanjo.com/files/PRIVATISATION\%20IN\%20NIGERIA.pdf, accessed 25June, 2013.

${ }^{6}$ See Comments by Professor Anya O. Anya, Chief Executive, The Nigerian Economic Summit at the Netherlands Congress Center (NCC), at the Hague as part of the Independence Day Celebration by The Nigerian Embassy at The Hague, available online at www.nigerianlawguru.com/.../company\%20law/PRIVATISATION\%20I...accessed 24 October, 2013.

${ }^{7}$ Jonathan Bradley, "Privatisation in Central and Eastern Europe: Models and Ideologies", Privatisation: Social Science Themes and Perspectives, Edited By: Derek Braddon and Deborah Foster, Centre for Social and Economic Research, Faculty of Economics and Social Science, University of West England, England \& USA: Ashgate Publishing Limited, 1996.
} 
interests, thus reducing the size of an overburdened public economy sector. ${ }^{8}$

Emeka Iheme defined privatisation as "any of a variety of measures adopted by government to expose a public enterprise to competition or to bring in private ownership or control or management into a public enterprise and accordingly to reduce the usual weight of public ownership or control or management. However in a strict sense, privatization means the transfer of the ownership (and all the incidence of ownership, including management) of a public enterprise to private investors". 9 The later meaning has the advantage of helping one to draw a line between privatisation and other varieties of public enterprise reform. It is also the sense in which the term has been statutorily defined in the legislations on privatization in Nigeria.

According to The Florida House of Representatives Committee on Governmental Operations, privatisation involves: engaging the private sector to provide services or facilities that are usually regarded as public sector responsibilities; shifting from publicly to privately produced goods and services; transferring government functions or assets, or shifting government management and service delivery to the private sector, attempting to alleviate the disincentive towards efficiency in public organizations by subjecting them to the incentives of the private market and using the private sector in government management and delivery of public services. Summarily it can be seen from definitions that privatisation involves ownership change from public to private ${ }^{10}$.

From the above definitions, we can see that privatisation is not limited to parastatals alone but can be viewed from a broader perspective of deregulation or reduction of state intervention on entire industries. It can also be seen from these definitions that privatisation basically involves transfer of ownership and management of public enterprises from state control to private hands for the purpose of achieving economic efficiency. ${ }^{11}$

3. The Philosophical Origin of the Concept of Privatisation

From our study, gamut of literatures reveals that privatization is not a new concept. Adam Smith (1776) in his book Wealth of Nations argued that: "In every great monarchy in Europe, the sale of the crown lands would produce a very large sum of money, which if applied to the payment of the public debts, would deliver from mortgage a much greater revenue than any which those lands have ever afforded to crown.... When the crown lands had become private property, they would, in the course of a few years, become well improved and well cultivated". The above statement is to sustain the claim that privatization is not new, rather the practice is what seems to be new. To different people and different schools of thought, privatization means different things. We believe that the origin of the idea of privatization is as old as the origin of the debate on private versus public ownership. Therefore its origin can be traced back to ancient Greece.

Thus, Plato thought private ownership and private property were evil, and favoured communal ownership. In "The Republic" Plato states that: “...Once they (guardians) start

\footnotetext{
${ }^{8}$ M. T, Okorodudu, "The Worker and Privatisation of Public Enterprises in Nigeria: A Legal Perspective", The Nigerian Current Law Review (198\$) pp. 134-154.

${ }^{9}$ See: Emeka Iheme, The Incubus: The Story of Public Enterprise in Nigeria, Lagos: The Helmsman Associates, 1997, $\quad$ p. 60 Available $\quad$ online http://www.nigerianlawguru.com/articles/company\%20law/READINGS\%20ON\%20PRIVATIZATION.pdf, accessed 29 August, 2013

${ }^{10}$ Eze Onyekpere (ed), "Challenges for the Privatisation Programme in Nigeria" in Readings on Privatisation in Nigeria, Lagos: Socio-Economic Rights Initiative SERI, 2003 at, p.52.

${ }^{11}$ The first definition of privatisation can, however, be qualified, in so far as the transfer may be total or merely partial. Holding all the shares in a firm is not the same as merely holding a majority or even a minority large enough to put a stop to certain decisions. Privatisation is thus partial if full ownership is not transferred. (For this also see: Stuart Butler, "Privatisation for Public Purposes", Privatisation and its Alternatives, Edited by: William T. Gormley, The University of Wisconsin Press, USA, 1991, p. 18); This definition agrees with the definition of Privatisation in Nigeria. See Public Enterprises (Privatisation-and Commercialisation) Act 1999 Cap. P30 Laws of Federation of Nigeria, 2004.
} 
acquiring their own lands, houses, and money, they will have become householders and farmers instead of guardians. From being the allied of the other citizens they will turn into hostile masters. ${ }^{12}$ "... I think that if they are going to be true guardians they should not have private houses, or land, or property of any kind, but that they should receive their livelihood from other citizens as payment for their guardianship, and all make use of these resources jointly ${ }^{13}$...It will stop them introducing private pleasures and pains along private property...since they have no private property apart from their own bodies, everything else being jointly owned..."14.

His student, Aristotle, however, thought communal ownership was insufficient; that it allowed the lazy to take advantage of the industrious: According to Aristotle: "...It is universal truth that men find difficulty in living together...especially when it comes to hold a property in common $^{15}$...it is evidently better, therefore, that property should be subject to private ownership...and it is special business of the legislator to make the necessary arrangements to that end... ${ }^{16}$ And yet by reason of goodness, and in respect of use we must take account not only of the disadvantages from which those who hold property in common will be saved, but also the benefits they will $\operatorname{lose}^{17}$...No legislator could hope to build a state unless he distributed and divided its constituent parts into associations for common meals on the one hand, and on the other into clans and tribes; and it is therefore obvious that Plato's suggested legislation does nothing more original that forbid the guardians to cultivate the soil... ${ }^{18}$.

From the ideological point of view, privatization is considered to lead to smaller government, lower taxes, and less government intervention in public affairs ${ }^{19}$. In that context, and that among economic and social theories, liberal theory seems to be the closest system to the idea of privatization, classical liberalism is often represented as a purely privatizing ideology. ${ }^{20}$

Liberalism refers to the following concepts: (a) limited government, in order to protect human liberty and avoid totalitarian regimes; (b) the virtues of free-market economics, the preservation of economic liberty and initiative in conjunction with the right to private ownership; and, (c) a civil rather than a political society in which the mediating institutions of the civil order are vibrant and provide the necessary constraints for the market and public morality. ${ }^{21}$ Therefore in the classical liberal constitutional order, ${ }^{22}$ the activities of government,

\footnotetext{
${ }^{12}$ G. R. F Ferrari (ed) Plato, "The Republic”, Translated by: Tom Griffith, Cambridge: Cambridge University Press, 2000, p. 163.

${ }^{13}$ Ibid. at, p. 252.

${ }^{14}$ Ibid, at p. 164.

${ }^{15}$ John Warnngton (ed), Aristotle's Politics and Athenian Constitution, London: J. M. Dent Sons, 1959, at p.35.

${ }^{16}$ Ibid.

${ }^{17}$ Ibid, at p. 36.

${ }^{18}$ Ibid, at p. $36-37$

${ }^{19}$ Paul Starr, "The New Life of the Liberal State: Privatisation and the Restructuring of State-Society Relations", available online at http://www.princeton. edu/ starr/newstate.html, accessed 12 June, 2013.

${ }^{20}$ Elizabeth Martinez and Arnoldo Garcia, "What is Neo-Liberalism?", web page of Corporate Watch, available online at http://www.corpwatch. org/trac/corner/glob/neolib.html, 12 June, 2013.

${ }^{21}$ M. A. Gregory Gronbacher, "The Philosophy of Classical Liberalism", web page of Acton Institute, available online at http://www, acton, org/cep/papers/classical/ib. html, accessed 12 June, 2013.

${ }^{22}$ Classical liberalism is a term used to describe a political philosophy commonly held in nineteenth century England and France. Classical liberal political thought has its beginnings in John Locke. Classical liberalism can be divided into several schools or branches, but the common strain throughout revolve around a strident defence of liberty in all its dimensions-social, political, and economic. At the heart of liberalism is a passionate commitment to the pursuit of liberty. Liberty as a political theory translates into a wider social vision. Classical liberals advocate free markets, a vibrant array of non-governmental institutions (such as civic groups, schools, churches, the free press, etc), and a minimum of tax-financed government services. Classical liberals firmly believe that government's first duty is to protect both persons and property from physical harm. They also emphasize the strict enforcement of contracts. Classical liberals, consider liberty to be the highest political value. Some examples of classical liberal thinkers include: John Locke, Frederic Bastiat, Adam Smith, David Hume, Francois de Voltaire, Adam Ferguson, Lord John Acton, Thomas Jefferson, John Stuart Mill, Herbert Spencer, Henry David Thoreau, Frederic Bastiat, Alexis de Tocquevile and Friedrich Hayek (Gregory M. A. Gronbacher,
} 
no matter how the agents are selected, are functionally restricted to the parameters for social interaction. Governments, ideally, were to be constitutionally prohibited from direct action aimed at "carrying out" any of the several basic economic functions like setting the scale of values, or organizing production, or distribution of the product.

These functions were to be carried out beyond the conscious intent of any person or agency; they were to be performed through the operation of the decentralized actions of the many economic participants, as coordinated by markets, and within a framework of laws and institutions that were appropriately maintained and enforced by government.

This liberal theory sees government or even the public sector as being an obstacle to economic development in recent times. In most cases, the liberals argue that government's intervention results in failure, which is a problem the government intervention meant to correct. Thus, this theory currently advocates increasing reliance on the market economy, through effective privatisation and commercialization of existing public enterprises, deregulation of domestic industries and markets and the liberalization of trade.

It can be rightly perceived that this theory forms the basis of which the World Bank/IMF - endorsed the Structural Adjustment Programmes (SAP) which Nigeria and many developing countries in serious economic crisis have adopted over the years.

Privatization in Nigeria was formally introduced by the Privatization and Commercialization Decree of 1988 as part of the Structural Adjustment Programmes (SAP) of then Military ruler, Ibrahim Badamosi Babangida's administration who ruled Nigeria between 1985 till 1993. As McGraw has argued, SAP is a neo-liberal development strategy devised by International financial institutions to incorporate national economies into the global market:

The vision of a "global market civilization" has been reinforced by the policies of the major institutions of global economic government up to the mid 1990s. Underlying the structural adjustment programmes has been a neo-liberal development strategy referred to as the Washington Consensus which prioritizes the opening up of nation economies to global market force and the requirement for limited government intervention in the management of the economy. ${ }^{23}$

One of the main objectives of SAP was therefore to pursue deregulation and privatization leading to removal of subsides reduction in wage bills and the retrenchment of the public sector ostensibly to trim the state down to size the public work force. ${ }^{24}$ The Structural Adjustment Programme, as implemented in Nigeria, consisted of a macro-economic policy reform which aimed at: having competitive real exchange rates, using prudent fiscal and monetary measures to improve the budget deficit position, achieving trade liberalization, privatising and commercializing Public Enterprises, down-sizing government and enlarging private sector role to serve as the engine of growth; and deregulating prices and markets. ${ }^{25}$

The above listed policy measures were based on the assumption that: the private sector was more efficient than the public sector, and as such, deserved to be encouraged to: play a more dynamic role in the economic development process; The allocation of resources and prices should be determined by the free interplay of market forces.

The neo-liberal theory blames the economic woes of the country on the public sector. It emphasizes the need to replace the public sector with the private sector in the economic

\footnotetext{
"The Philosophy of Classical Liberalism", web page of Acton Institute, available online at http://www. acton, omcep/papers/classical/ib. html, 21 June, 2013. "Historical Roots of Libertarianism", available online at http://www.libertarian.org/history.html. accessed 21 June, 2013.

${ }^{23} \mathrm{~A}$. Me Grew, "Sustainable Globalization? The Global Politics of Development and Exclusion in the New world order" in Allen, T. and Thomas, A (eds), Poverty and Development into the $21^{\text {st }}$ Century. New York: Oxford Universities Press Inc. 2000.

${ }^{24}$ S.G. Egwu, "Structural Adjustment, Agrarian Change and Rural Ethnicity in Nigeria". Research Report No. 103. Uppsala, Sweden, the Nordic African institute 1998.

${ }^{25}$ Ibid.
} 
development process. Under this theory, the public sector is expected to play supportive roles in the economic development process. This paradigm shift has been tagged, "Governance Led Development Theory" ${ }^{26}$ and its central theme is that good governance provides the lead in the development process.

Within this framework, governance is perceived as the "good government of a society which guides the country along a course leading to the desired economic development". The term embraces three distinct but intimately related dimensions of politics, techniques and institutions. The establishment of good development objectives to guide the private sector and the exercise of proper leadership are identified with the political dimensions. ${ }^{27}$

It is important to note from the foregoing theoretical expositions that both the market system and state intervention could be necessary for the economy at its different development stages. However, it will be crucial under neo-liberal thesis for an interventionist state to intervene by merely strengthening the existing market institutions. Besides, it will also be necessary to create or stimulate such markets, where one exists, in order to influence the behaviour of economic agents, effectively.

Thus, within a market-oriented economy, the state's role will be that of promoting and supporting the right type of market institutions to allow for effective private sector dominance of economic activities. Nevertheless, in a crisis-ridden economy, the role of the state (public sector) will hinge on the severity of the crisis, and of course, the developmental stage of the economy. $^{28}$

To us, the liberal theory seems to be the closest system to the idea of privatization, the connection between liberalism and privatization should be made with caution and the following points need to be taken into account in evaluating this link:

(a) In the course of this paper, privatization and liberalization will be viewed from two different concepts. Liberalization refers to the opening up of any industry to competitive pressures. $^{29}$ In other words, liberalization refers to the abolition or relaxation of the monopoly powers of nationalized industries.

The opening up of public monopolies to private entrepreneurs is a form of privatization (in terms of broader understanding of privatization) that is also liberalizing in its nature. However, it is entirely possible to privatize without liberalizing, by selling shares of monopolies without significantly subjecting them to competitive forces.

Conversely, it is also possible to liberalize without privatizing, that is to introduce competition into public sector without transferring ownership. ${ }^{30}$ Governments can also privatize and liberalise together by both selling state enterprises and deregulating entry into their markets

\footnotetext{
${ }^{26}$ Quoted in Allene O. Esther, "Implementation of Privatisation Policy in African Petroleum PLC", unpublished thesis for M.Sc (Public Administration) Obafemi Awolowo University, Ile- Ife (2004).

${ }^{27}$ James M. Buchanan, "Notes on the Liberal Constitution", the Cato Journal, Vol. 14, No. 1, available online at hhp://wmw. cato. org/pubs/joumal/cj14nl-l.html, accessed 24 June, 2013.

${ }^{28}$ For detailed discussion on this theory, see: Bulent Seven, above note 1, at pp.8-18.

${ }^{29}$ In Nigeria, petroleum, energy, power, communication and recently the power sectors have now been liberalized. Liberals favour competition. For example, Hayek states that: "... competition (is) superior... not only because it is in most circumstances the most efficient method known, but even more because it is the only method by which our activities can be adjusted to each other without coercive or arbitrary intervention of authority. See also F. A. Hayek, The Road to Serfdom, Rome and London: George Routledge \& Sons Ltd, 1944, p. 27. "... competition operates as a discovery procedure not only by giving anyone who has the opportunity to exploit special circumstances the possibility to do so profitability, but also by conveying to the other parties the information that there is some such opportunity. It is by this conveying of information in coded form that the competitive efforts of the market game secure the utilization of widely dispersed knowledge...”. F.A. Hayek, Law, Legislation, and Liberty-Volume-2-The Mirage of Social Justice, London and Henley: Routledge \& Kegan Paul, 1976, p. 117.

${ }^{30}$ Paul Starr, "Limits of Privatisation", Proceedings of the Academy of Political Science, Vol. 36, No. 3, Prospects for Privatization, 1987, pp. 124-13, at p. 110.
} 
as it is currently been done by Nigeria. ${ }^{31}$ Finally it is even possible to nationalize and liberalise at the same time ${ }^{32}$ (as the French socialists demonstrated in the early 1980s, and Nigeria indigenized the banking and insurance sectors in early and mid 1970s, both countries first nationalized banks and later liberalized financial markets).

(b) Secondly the trend toward privatization might be explained in straightforward political and ideological terms if those developments had been limited to liberal governments. However, privatization have been adopted by labour governments in Britain (particularly under the Labour Party), New Zealand and Australia, Spain (under socialist governments), and by a variety of countries with more mixed regimes as different as those of Japan and Mexico.

Again, Russia, Poland and other nations that were under the repressive influence of Soviet Union which are now enthusiastically pursuing fundamental economic reforms, top on the agenda of which is privatization. In the case of African Countries and other third world countries commonly described as the Least Developed Countries (LDCs) of the world, privatization came as a Greek gift embedded in the Structural Adjustment Programs (SAP) designed by the International Monetary Fund (IMF) as the elixir for the economies of the perpetually heavily indebted nations who while praying for cancellation of their debts are at the same time demanding more credit. These countries, of which Nigeria is one, were for the most past, nations under authoritarian regimes with scant regard to efficiency and accountability in the management of State resources. ${ }^{33}$

Countries, such as Nigeria, that not long ago, were nationalizing multinationals have been inviting new foreign investments and selling off pieces of the public sector ${ }^{34}$. Socialist governments throughout Western Europe now seem more keen on liberalizing markets than on seizing control of the means of production. ${ }^{35}$

China exemplified a case of a partial privatization, where workers in three state-owned factories in southern China have invested \$2.9 million USD to buy 30 percent of the enterprises and further to that some state owned homes were sold ${ }^{36}$.

(c) Privatisation may ultimately result in less state control, but it first requires states to develop capacities not previously had, such as the capacity to maintain the rule of law, instill confidence among investors, supervise contracts, and provide expedient administration of official rules and regulations. ${ }^{37}$ Government will still need to regulate a delivered service even though it has been privatized, since privatizing a service does not leave government without responsibilities. Issues of public safety, public health, and quality of service will arise ${ }^{38}$.

\footnotetext{
${ }^{31}$ In Nigeria, the federal government has divested all its equity holdings in every Bank in the country under the current privatization programme. The petroleum, energy, communication, power sectors have been deregulated or liberalised.

${ }^{32}$ Paul Starr, “The Meaning of Privatization”, Yale Law and Policy Review 6 (1988): 6-41. Reprinted in Alfred Kahn and Sheila Kamerman, eds., Privatization and the Welfare State Princeton University Press, 1989. Available online at, http://www.princeton. edu/starr/meaning.html. 24 June, 2013

${ }^{33}$ Kalu Onuoha "The Legal Regulation of Privatisation: A Critique", in Eze Onyekpere (ed), above note 10, at, p. 9.

${ }^{34}$ See, Z.O. Aje, "Indigenisation of Enterprises in Nigeria", an unpublished Ph.D thesis submitted to the School of Postgraduate Studies, University of Lagos, Nigeria, 1978.

35 Paul Starr, "The New Life of the Liberal State: Privatisation and the Restructuring of State-Society Relations", available online at http://www.princeton.edu/ starr/newstate.html, accessed 16 July, 2013.

${ }^{36}$ Peter Young, "Privatisation around the World", Proceedings of the Academy of Political Science Vol. 36, No. 3, Prospects for Privatization (1987), p. 193, 205. According to Young ... "Throughout the world socialism has been revealed as a failed ideology. It neither delivers the goods nor provides the motivation....". Also see also, "Cautious Privatisation in China", web page of Le Monde Diplomatique, available online at http://www.monde-diplomatique.fr/en/1997/ll/china; accessed 20 July, 2013.

${ }^{37}$ Paul Starr, above note 19.

${ }^{38}$ Robert W. Bailey, "Uses and Misuses of Privatisation”, Prospects for Privatisation, edited by H. Steve Hanke, ASP (Proceedings of the Academy of Political Science), Volume 36, Numbers, New York, 1987, p. 148, Even liberals believe that regulation is needed. Thus according to Hayek; “...special regulations for the use of facilities
} 
Therefore, privatization does not mean that public administration will disappear.

While it is believed that in the privatization movement ideological factors and considerations are important, the underlying impetus for privatization, however, has been practical. ${ }^{39}$ For example one pragmatic approach was that the fact that State Owned Enterprises (SOEs) were losing money and many of them were in deep financial crisis, politicians found it easy to sell and get rid of SOEs instead of raising taxes. ${ }^{40}$ Similarly, privatization diverts claims away from the state. Just as employment is privatized, so too are consumer dissatisfactions privatized. $^{41}$

This research underscored the impact of privatization to reviving the ailing national industries and further observed that worldwide, both liberal and socialist governments have been implementing privatization processes. It therefore argued that privatization represented a pragmatic solution to specific administrative, financial and economic problems.

It is noteworthy that with the collapse of socialism in the 1930s and 1990s, liberalism was the only player in the field of economic advancement of nations. According to Fukuyama: "...liberal democracy may constitute the-end point of mankind's ideological evolution and the final form of human government, and as such constituted the end of history" ${ }^{42}$ It is arguable whether the liberal democracy is the end of the history but our analysis revealed that, since the launch of first privatization efforts, the concept of privatization has lost its ideological character and turned into a pragmatic economic and social instrument that almost all governments have adopted around the world. In other words, this paper considered privatization as a "pragmatic" approach instead of an ideological approach; it cannot be attached purely to one ideology or system in any political economy.

Also, this paper believed that the global economic recession which started in America as a mortgage financing problem in year 2007 and has now compelled all European, American and virtually every government all over the world to be providing huge sums of money to bail out financially distressed banks and companies could be seen as a return to socialism. The government of United States of America has purchased non-voting shares in the three large American car producing companies- Crysler, Ford and General Motors as part of the terms for financial bailout for the companies ${ }^{43}$. It is not inconceivable that the Nigeria government will in future buy back its equity in the banks which it sold in $1992^{44}$. A more recent socialist approach to privatization was exhibited by Nigeria in the bailout by the Federal Government of Nigeria of four banks that are at the brink of collapse or liquidation viz: Afribank, Spring Bank and Bank PHB and were nationalised in 2011. Assets Management Corporation of Nigeria (AMCON), a Nigerian agency then recapitalised them and changed their names to Mainstreet Bank,

provided by government for the public are undoubtedly necessary...”. See also F.A. Hayek, Law Legislation and Liberty Volume 3 the Political Order of a Free People, Routledge \& Kegan Paul, 1979, at p.48.

${ }^{39}$ Therefore in many countries both liberal and socialist governments have adopted privatization programmes. For example in Austria all major parties implemented privatisation programmes: Vincent Wright (ed) "Privatisation in Western Europe - Pressures, Problems and Paradoxes" Pinter Publishers, Great Britain, 1994. Similarly, privatisation has not been an ideological issue in the Netherlands. (B. Rudy Andeweg, "Pnvatisation in the Netherlands: The Results of a Decade", "Privatisation in Western Europe-Pressures, Problems and .Paradoxes, Vincent Wright (ed), Great Britain: Pinter Publishers, 1994, p.199. Andeweg states that: “... Dutch privatisation (is) neo corporatist/bureaucratic, not party political...".

${ }^{40}$ Thus for example in the United Kingdom it became political to regard privatisation receipts as a means by which tax cuts could be financed without the need to cut public expenditure. Peter Curwen, Privatisation in the United Kingdom, The Facts and Figures, published by Ernst \& Young, 1994.

${ }^{41}$ Paul Starr, above note 19.

${ }^{42}$ Francis Fukuyama, The End of History and the Last Man, England: Penguin Books, 1992, at p. xi.

${ }^{43}$ Curled from C.N.N. News (Cable News Network) of at 9p.m on 11 December, 2008.

${ }^{44}$ J. O. Ekundayo in "Privatisation of Government Owned Banks and the Issue of Ownership and Control...," 1996 N.I.A.LS. p. 43. The Nation Newspaper of 2 February, 2009 reported at page 4 that the Federal Government of Nigeria is to re-acquire banks shares. Similarly, CNN News Report of 17 December, 2009 at 9.pm said that Germany is to renationalize banks. 
Enterprise Bank and Keystone Bank, respectively. AMCON holds the non-performing assets of troubled banks in Nigeria. ${ }^{45}$ This paper having espoused in detailed manner the philosophical, political and ideological theories of privatization, the definitions and origin of privatization, we shall in the next sub-issue, examine the methods of privatization applied by modern political societies.

\section{Examining the Different Non-divestiture Methods of Privatisation}

Under this sub-heading, the authors will examine the different non-divestiture methods of privatization being practiced by different countries and these are as follows: Subcontracting or contracting out, Management contract, Franchising contract, Leases, Built-Operate-Transfer, Build-own operate, Build-Transfer-Operate and Universal Service Obligations.

(i). Subcontracting (contracting out). This is where the public agency that previously conducted the activity now subcontracts its execution to a private party. ${ }^{46}$ In Nigeria, contracting-out has been used in revenue collection for government, hostel management in Universities, ward cleaning in hospitals, and security management in government establishments. Furthermore, contracting out can take many forms, including the relatively straightforward award of a contract for services, long-term arrangements that involve innovative private project financing, lease-back of capital equipment, or long-term per-unit fees for service $^{47}$. The public agency or authority may contract with a private firm or individual, but it may also contract out to voluntary or co-operative organizations, or in some cases to other public sector agencies.

Under contracting out arrangements, public authorities continue to bear direct responsibility both for the provision arrangements and for the quality of service provided although the work is actually carried out by the employees of private firms. ${ }^{48}$

(ii). Management contracts: These contracts are agreements between government and a private company, in which government pays a fee to the private company for managing the State Owned Enterprise (SOE). These contracts are common in hotels, and airlines. Management contracts are usually less politically contentious than sales. They avoid the risk of asset concentration, and can enhance productivity. Governments nonetheless tend to prefer sales for a number of reasons. Typically, contractors do not assume risk; operating losses must be borne by the owner (the state) even though it has relinquished day-to-day control of the operation. Many standard management contracts are flat fee for service arrangements, payable regardless of profits, which provide little incentive to improve efficiency. Further, unless proper legal safeguards are developed, and enforced by monitoring, there is a risk that the contractor may run down the assets. Another drawback is that few management contractors provide adequate training for local counterparts. These risks can be reduced with properly drawn-up

\footnotetext{
45 Oyetunji Abioye “AMCON Seeks Buyers for Enterprise Bank”, Punch Newspaper, 3 September 2013, available online at http://www.punchng.com/business/business-economy/amcon-seeks-buyers-for-enterprisebank/, accessed 5 November, 2013.

${ }^{46}$ Sometimes it is referred to as "outsourcing". Outsourcing [is, however, different from contracting out. Under outsourcing a government entity remains fully responsible for the provision of affected services and maintains control over management decisions, while another entity operates the function or performs the services. This approach includes contracting out, the granting of franchises to private firms, and the use of volunteers to deliver public services. According to the definition of General Accounting Office of USA: "Contracting out is the hiring of private-sector firms or non-profit organizations to provide goods or services for the government Under this approach, the government remains the financier and has management and policy control over the type and quality of goods or services to be provided. Thus, the government can replace contractors that do not perform well”. In the U.S, the term has often been broadly applied to the contracting out of the management of public schools, prisons, airports, sanitation services, and a variety of other government-owned institutions, especially at the state and local levels.

47"Harnessing the Market: The Opportunities and Challenges of Privatisation", Department of Energy of USAPrivatisation, available online at http//www.osti.gov., accessed 16 August, 2013.

48 Ibid.
} 
contracts, but that requires strengthening government's capacity to negotiate, monitor and enforce contractual obligations. ${ }^{49}$

(iii). Franchising contract: This is where the government grants a concession or privilege to a private sector entity to conduct business in a particular market or geographical area-for example, operating concession at ports, hotels, and other services provided in certain public places. The government may regulate the service level or price, but users of the service pay the provider directly ${ }^{50}$. In Nigeria, for example private firms were granted concession on to operate the Nigerian ports. ${ }^{51}$

(iv). Leases: This is another form of privatisation which has overcome some of the drawbacks to management contracts. In leases, the private party, which pays the government a fee to use the assets, assumes the commercial risk of operation and maintenance, and thus has greater incentives (and obligations) to reduce costs and maintain the long-term value of the assets. Hence, fees are usually linked to performance and revenues. ${ }^{52}$ In other words in the lease-and-operate contract, private contractor is responsible at its own risk for provision of the service, including operating and maintaining the infrastructure, typically against payment of a lease fee. ${ }^{53}$ Furthermore, if the lease includes an option to buy, the operation could be regarded as a divestiture. ${ }^{54}$

(iv). Built-Operate-Transfer: With Build-Operate-Transfer (BOT) arrangements, the private sector designs, finances, builds, and operates the facility over the life of the contract. At the end of this period, ownership reverts to the government.

(v). Build-own operate (BOO) is a similar scheme as BOT but does not involve transfer of the assets. ${ }^{55}$ With Build-Own-Operate (BOO) arrangements, the private sector retains permanent ownership and operates the facility on contract. ${ }^{56}$

(vi). Build-Transfer-Operate: A variation of BOO and BOT, is the Build-TransferOperate (BTO) model, under which title transfers to the government at the time construction is completed. $^{57}$

(vii). Universal Service Obligations: This form of contract requires the private company in charge of providing the service to give access to all groups in the area of the concession, regardless the level of income. In the case of Universal Service Obligation (USO), the contract must also specify pricing schemes (possibility of cross-subsidies) and mechanisms for public subsidies when they are necessary. ${ }^{58}$

At this point, it will be necessary to examine the concept of privatization in Nigeria since the idea of transferring state owned enterprises to private individuals and organization for effective management in Nigeria have gained ground in Nigeria since the regime of General

\footnotetext{
${ }^{49}$ J. R. Nellis, and M. M. Shirley, Privatisation: The Lessons of Experience, Washington DC: The World Bank Publications, 1992, p. 25-26.

50، Terms Related to Privatisation Activities and Processes", July 1997 GAO (General Accounting Office of USA), available online at http://www,privatistaion.org/ accessed 20 August, 2013.

${ }^{51}$ In Nigeria, concessions for ports were granted to Dangote Groups of Companies Flour Mills (Nig) Ltd and ENL (Nig) Ltd.

${ }^{52}$ Lease arrangements have been widely used in Africa, particularly in sectors when it is difficult to attract private investors. (Privatizing State-Owned Companies:, The Prosperity Papers Series, Prosperity Paper Three web page of Centre for International Private Enterprise, available online at http//www. Cipe.org/), accessed 20 August, 2013.

${ }^{53}$ Pierre Guislain and Michel Kerf, "Concessions-The Way to Privatise Infrastructure Sector Monopolies", Public Policy for the Private Sector, The World Bank, Note No 59, October 1955.

${ }^{54}$ Pierre Guslain, The Privatization Challenge: A Strategic, Legal, and Institutional Analysis of International Experience, Washington DC: World Bank Publications, 1997, p. 10.

${ }_{56}^{55}$ Pierre Guislain and Kerf, above note 53 at p.1.

56 "Types and Techniques of Privatisation", Privatisation Database, available online at http://www.privatisation.org, accessed 20 August, 2013.

57 Ibid.

${ }^{58}$ Ibid.
} 
Ibrahim Babangida as noted earlier in the course of this paper. Even though references have been made above to the privatization process in Nigeria, this paper in the next sub-issue will examine in a more holistic manner, the concept of privatization in Nigeria.

\section{The Concept of Privatisation: the Nigeria Experience}

The privatization process in Africa is not peculiarly African. ${ }^{59}$ To a large extent, it is part of the globlisation process. ${ }^{60}$ According to Otive Igbuzor, the participation of the state in enterprises in Nigeria dates back to the colonial era. The task of providing infrastructural facilities such as railways, roads, bridges, water, electricity and port facilities fell on the colonial government due to the absence of indigenous companies with the required capital as well as the inability or unwillingness of foreign trading companies to embark on these capital-intensive projects. ${ }^{61}$ This involvement was expanded and consolidated by the Colonial Welfare Development Plan (1946-56) that was formulated when the labour party came to power in the United Kingdom. This trend continued after independence such that by 1999, it was estimated that successive Nigeria Governments have invested up to 800 billion naira in public owned enterprises. $^{62}$

In Nigeria, privatization process started with the concept of "Privatisation and Commercialization" which was introduced in Nigeria in 1988, The Privatisation and Commercialisation Act $1988^{63}$ provided the legal and institutional framework for the programme. In 1993, the Technical Committee on Privatisation and Commercialisation (TCPC) which was set up under the 1988 Act completed its work of privatistaion and commercialization of specific enterprises listed in the schedules to the Act and submitted its final reports.

Following the recommendations of the TCPC, the Federal Government designed a new phase of the programme and, by virtue of the Bureau for Public Enterprises Act 1993 (now repealed) replaced the Act of 1988. The Act of 1993 introduced rules and set up a new agency to continue the programme. In 1999, the Federal Government again revisited the programme and enacted the Public Enterprises (Privatisation and Commercialisation) Act $1999^{64}$, which in turn repealed and replaced the Act of 1993. The Act of 1999 is the statute that currently regulates the programme.

In both the Privatisation and Commercialisation Act 1988, and the Bureau of Public Enterprises Act 1993, "privatization" is defined as "the relinquishment of part or all the equity and other interests held by the Federal Government or any of its agencies in enterprises whether wholly or partly owned by the Federal Government". 65

With respect to the commercialization component of Privatisation in Nigeria, much unlike in other countries that have embarked upon a programme of public enterprise reform, the Federal Government of Nigeria introduced privatization along with a programme of Commercialisation. Commercialization was conceived as an alternative to the privatization of sortie public enterprises. The Act of 1988 defined commercialization as "the reorganization of an enterprise wholly or partly owned by the Federal Government in which such

\footnotetext{
${ }^{59}$ R. Munyonyo, "The Privatisation Process in Africa: Ethical Implications", Chapter VI, available online at http://www.crvp.org/book/Series02/II-8/chapter_vi.htm, accessed 20 August, 2013.

${ }^{60}$ Yash Tandon defines globalisation as "the final conquest of capital over the rest of the world." However, he credits globlisation with "the spread of cultural pluralism, the development of technology and productive forces, the global awareness of the underlying unity of humankind, and more recently the (partial) return to nature as an inherent part of life in all its many forms." Tandon Yash, "Globalization and Africa's Options, International South Group Network, Monograph No. 2, 1999, p. 3.

${ }^{61}$ E. Iheme, above note 9.

${ }^{62}$ Otive Igbuzor, above note 4 , at p.36.

${ }^{63}$ Cap 369 Laws of Federation of Nigeria, 1990 now repealed.

${ }^{64}$ Public Enterprises (Privatisation and Commercialisation) Act 1999, now Cap P38 Laws of Federation of Nigeria, 2004.

${ }^{65}$ The word is not defined in the Public Enterprises (Privatization and Commercialisation) Act 1999 but there is no doubt that it is in that sense that the word is used in the Act.
} 
Commercialised enterprises shall operate as profit making commercial venture and without subventions from the Federal Military Government" ${ }^{66}$

The economic principles of deregulation and privatisation were first introduced in Nigeria in the1980s through the policy of Structural Adjustment Programme (SAP). Since then, government monopolies had disappeared in many industries. According to Kudus Adebayo, over 85 Public Enterprises in mining, education, health, agriculture, transportation and telecommunication were transferred, either fully or partially, to private owners. The idea of deregulation and privatisation were welcomed policies of government for several reasons that range from the demand for efficiency and effectiveness in public enterprises to the need for accountability, generation of employment, curb external borrowing, and strengthen the capital market amongst others. ${ }^{67}$ This paper will now engage in a cursory examination of the method used for achieving the concept of privatization in Nigeria having underscored the policy issues behind deregulation and privatisation in Nigeria.

\subsection{Full and Partial Privatisation in Nigeria}

Our research reveals that the process of privatisation involves full and partial modes of privatisation. Privatisation can also be classified according to the privatization techniques, considering the level of investment responsibility and the degree of the risk transferred to the private sector, and to the relative irreversibility of the privatisation transaction.

The Public Enterprises (Privatisation and Commercialisation) Act list four categories, and affected enterprises. Category I, are enterprises in which equity held by government shall be partially privatized. Category II, represents enterprises in which $100 \%$ of equity held by government shall be fully privatized. Category III, contains enterprises to be partially commercialized; while category IV are enterprises to be fully commercialized. We may tend to ask ourselves that what then do the terms "full" and "partial" privatisation, and "full" and "partial" commercialization mean? The Act itself provides no definitions. However, the Guidelines on Privatisation and commercialization of Government Enterprises (hereinafter referred to as "the Guidelines") do. ${ }^{68}$

According to the Guidelines, full privatisation means the "disinvestment by the Federal Government of Nigeria, of all its ordinary shareholding in the designated Enterprise". Partial privatisation on the other hand, means the: "disinvestment by the Federal Government of part of its ordinary shareholding in the designated enterprise". 69

In the course of writing this paper, the authors learnt that the first economic argument for partial privatisation follows from the difficulty of determining a fair price for the enterprise in an uncertain environment. The second economic argument follows from the difficulty of actually obtaining a fair price for the enterprise, even if it can be determined, when the offering is large relative to the existing capital market. Selling part of the shares initially, letting the market set a price over time, and later selling the rest can thus increase government revenues. ${ }^{70}$

\footnotetext{
${ }^{66}$ Public Enterprises (Privatisation and Commercialisation) Act 1999, now Cap P38 Laws of Federation of Nigeria, 2004.

${ }^{67}$ Kudus Adebayo, "Deregulation and Privatisation in Nigeria: Benefits and Challenges", Paper Prepared for Industrial Sociology Seminar in the Department of Sociology, University of Ibadan March 2011, at p.4, aavailable online

http://www.academia.edu/2357107/Deregulation_and_Privatisation_in_Nigeria_Benefits_and_Challenges, accessed 22 October, 2013.

${ }^{68}$ Ibid.

${ }^{69}$ See Section 6 paragraph 4(a) and (b) of the Guidelines on Privatisation and Commercialisation in Nigeria, available online at www.nigeria.gov.nig. Accessed 11 October, 2013 (See the website of BPE the agency for privatisation in Nigeria). There is also a variation of partial sale in the case of fragmentation, or breaking up and/or restructuring. SOE into component parts and selling them separately. In Nigeria the National Electric Power Authority was broken into pdwer generation, transmission, and distribution companies. See Federal Government Gazette. No. 24 Vol.91 of 1/3/2003

${ }^{70}$ Full privatization is the transfer of $100 \%$ of ownership and control to the private buyer or buyers; partial divesture is anything less. Partial divesture in turn reflects a continuum of choice on the ownership scale but a
} 
The political arguments for partial privatisation is that, in the presence of contending political forces, the alternative to the compromise of partial privatisation may be no privatisation, at least for the time being.

In Nigeria, as in many other countries, partial privatisation has been undertaken as a strategy of gradual introduction of a company into the stock market, for reason related to the perceived absorption capacity of the later. That has been the case in the British (British Gas), Spanish (Telefonical, Argentaria) Kalian (ENI, Telecom Italia), France Telecom and Royoe KPN of the Netherlands. These companies have been only partially floated with the state intending to remain a controlling shareholder. Some of the smaller economies have kept large stakes of their utilities (telecoms Jin Czech Republic, and electricity in Belgium), after having sold important minority stakes to strategic foreign investors, Partial privatization, in some circumstances that were mentioned above, may improve both the country's economic welfare and the government's political well being.. ${ }^{71}$

As part of the guidelines on privatisation and commercialisation, under the privatisation programme as announced on July 20, 1998 by former military Head of State, General Abdulsalami Abubakar, Government will retain $40 \%$ of the telecom, electricity, petroleum refineries, coal and bitumen production, tourism, and spill-overs from the first phase of privatisation equities of the affected enterprises whilst $40 \%$ will be alienated to strategic investors with the right technical, financial and management capabilities. The remaining $20 \%$ will be sold to the Nigerian public through the Stock Exchange. President Olusegun Obasanjo in his Presidential order to the Vice President of the Federal Republic of Nigeria dated 6th July 1999, directed that as the first step in the phased implementation of the administration's privatisation programme, action was to be initiated to enable the sale of shares listed on the Lagos Stock Exchange and owned by the Federal Government and its agencies in: Commercial and Merchant Banks, Cement Plants and Petroleum Marketing Companies. ${ }^{72}$ The sales were supposed to be completed by December, 1999 and Core Investors are to be encouraged to buy into any of the privatised enterprises. The second phase consisted of hotels and vehicles assembly plants, amongst others. The third phase will involved work on the companies being prepared for privatisation including NEPA (PHCN), ${ }^{73}$ NITEL, NAFCON, Nigeria Airways,

discontinuity on the control scale, depending on whether or hot control/ing interest is sold. See Guislain, above note 54 , at p. 11 .

${ }^{71}$ Stilpon Nestor and Ladan Mahboobi, "Privatisation of Public Utilities", The OECD Experience, Rio-9 Doc. 22 April, 1999, at p. 27.

${ }^{72}$ Nigeria: Embassy of the Federal Republic of Nigeria, Washington D.C, "Guidelines on Privatisation and Commercialisation" available online at http://www.nigeriaembassyusa.org/index.php?page=privatisation, accessed 23 October, 2013.

${ }^{73}$ Ibid, The first coordinated approach towards electricity development in the Nigeria was in 1950 when the colonial government passed the Electricity Corporation of Nigeria (ECN) Ordinance 15. The ordinance established the ECN which took over the work of the electricity department as well as the generating plants that had been established in different parts of Nigeria. National Electric Power Authority (NEPA) was an amalgam of the Niger Dam Authority and the Electricity Corporation of Nigeria. Although the authority was proclaimed by the Military Administration of General Yakubu Gowon on April 1, 1972, it started operation in January 1973. Because of NEPA's poor operational and financial performance, the Federal Government of Nigeria (FGN) amended the then prevailing laws (Electricity and NEPA Acts) in 1998 to remove NEPA's monopoly and encourage private sector participation. FGN established the Power Holding Company of Nigeria (PHCN) the initial holding company) and subsequently unbundled it into eighteen (18) successor companies. Strategically, the objectives of the reform include (i) the transfer of management and financing of SC operations to the organised private sector; (ii) the establishment of an independent and effective regulatory commission to oversee and monitor the industry; and (iii) focusing the FGN on policy formulation and long-term development of the industry. This will lead to (i) increased access to electricity services; (ii) improved efficiency, affordability, reliability and quality of services; and (iii) greater investment into the sector to stimulate economic growth. The successor companies that were handed over to the new investors include Abuja Distribution Company (owned by KANN Consortium Utility), Benin Distribution Company (Vigeo Power Consortium), Eko Distribution 
Refineries, etc. ${ }^{74}$

The following are Nigeria Parastatals that were listed for privatisation, these enterprises are under the key sectors of the economy such as communication, energy, industry and manufacturing, natural resources, ports, power, services, transport and aviation and among them are: Nigerian Postal Service, Nigerian Telecommunication, Eleme Petrochemicals Company Limited, Kaduna Refining \& Petrochemical Company Limited, Nigeria Gas Company Limited, Pipelines and Products Marketing Company (PPMC), Port Harcourt Refining Company Limited, Stallion Property and Development Company Limited, Warri Refining and Petrochemicals Company Limited, Anambra Motor Manufacturing Company Limited, Electric Meter Company of Nigeria, Federal Super Phosphate Fertilizer Co Limited, ${ }^{75}$ Iwopin Pulp and Paper Company, Lafiaji Sugar Company Limited, LEYLAND, National Fertilizer Company of Nigeria (NAFCON), Nigeria Romania Wood Industry, Nigeria Sugar Company Limited, Nigeria Unity Line Plc, Nigerian Machine Tools Limited, Nigerian Newsprint Manufacturing, Peugeot Automobile Nigeria Limited, Steyr Nigeria Limited, Sunti Sugar Company Limited, Volkswagen of Nigeria, Ajaokuta Steel Company Limited, Ayip-Eku Oil Palm, Delta Steel Company, Ihechiowa Oil Palm Company Limited, Jos Steel Rolling Company, Katsina Steel Rolling Mill Company, National Iron Ore Mining Company Limited, Nigeria Uranium Mining Company, Nigerian Coal Corporation, Nigerian Mining Corporation, Oshogbo Steel Rolling Mill Company, River Basin Development Authority, Nigerian Ports Authority, National Electric Power Authority, Abuja International Hotels (Le Meridian), Abuja National Stadium, Abuja Stock Exchange, Afribank Nigeria PLC, Bank of Industry, International Conference Centre Abuja, Lagos International Trade Fair, National Theatre, NICON Insurance Corporation, Nigerian Agricultural Bank, Nigerian Film Corporation, Nigerian Television Authority, Tafawa Balewa Squrae Investment Limited, Federal Airports Authority of Nigeria, Inland Waterways Authority, National Clearing and Forwarding Agency (NACFA), Niger Dock Nigeria PLC, Nigeria Airways Limited, Nigeria Airways Subsidiaries, Nigerian Aviation Handling Company Limited, Nigerian Railway Corporation, and Railway Property. ${ }^{76}$ It is important to state that most of these enterprises have either gone underground, privatised or awaiting privatisation.

In the case of Nigeria, as aptly described by Professor Anya O. Anya, "the issue of mismanagement and under-utilisation which led to huge wastage of resources and manpower potentials gave the government no other option but to pursue a privatisation programme. There are about 600 public enterprises in Nigeria run by or controlled by the Federal Government.

Company (West Power \& Gas), Enugu Distribution Company (Interstate Electrics Ltd) and Ibadan Distribution Company (Integrated Energy Distribution \& Marketing Limited). Others are Ikeja Distribution Company (NEDC/KEPCO Consortium), Jos Distribution Company (Aura Energy Limited), Kano Distribution Company (Sahelian Power SPV Limited), Port Harcourt Distribution Company (4 Power Consortium) and Yola Distribution Company (Integrated Energy Distribution \& Marketing Limited). The generation companies expected to be handed over are Shiroro (owned by North-South Power Company), Kainji (Mainstream Energy Solutions Ltd), Geregu (Amperion Power Distribution) and Ughelli (Transcorp Ughelli Power Plc).... this handing over is a culmination of 14 years of painstaking effort by the NCP, BPE and other key stakeholders to reform and liberalise Nigeria's electricity industry, which began in 1999. The official handing over of physical assets of the defunct Power Holding Company of Nigeria (PHCN) to new owners by the Federal Government took place on 1 November, 2013. See, Tunde Dodondawa, Leon Usigbe and Paschal Okeke, "Nov 1 handing over: PHCN workers embark on strike", Nigerian Tribune, 1 November, 2013. See Everest Amaefule "Power Sector: Slowly, Nigeria on the path of recovery", Punch Newspaper, 1 October, 2013. Available online at, http://www.punchng.com/nigeria-53/slowly-nigeria-on-the-path-of-recovery/ accessed 30 October, 2013. See also Nigeria $\quad$ Electricity Privatisation Project (PHCN), available online at http://www.nigeriaelectricityprivatisation.com/?page_id=2, accessed 30 October, 2013. ${ }^{74}$ Ibid.

75 Nigerian Government Companies Listed for Privatization", available online http://www.nairaland.com/46829/nigerian-govt-companies-listed-privatization, accessed 29 October, 2013. ${ }^{76}$ Ibid. 
Many more are controlled by State Governments. ${ }^{77}$ These companies take a sizeable portion of the Federal Budget and account for over 5,000 appointments into their management and Board. Transfers to these enterprises ran into billions of naira". ${ }^{78}$

These transfers were in form of subsidized foreign exchange, import duty waivers, tax exemptions and/or write-off of arrears, unremitted revenues, loans and guarantees and grants/subventions. These companies were also infested with many problems which became an avoidable drag on the economy such as abuse of monopoly power, defective capital structure, heavy dependence on treasury funding, rigid bureaucratic structures and bottlenecks, mismanagement, corruption and nepotism. With all these problems the government had no other option but to take a positive step. ${ }^{79}$ The reform as conceived has two interrelated components-Privatisation and Commercialisation. The overall objectives of the privatization exercise were: to improve on the operational efficiency and reliability of our public enterprises; to minimise their dependence on the national treasury for the funding of their operations; to roll back the frontiers of State Capitalism and emphasised private sector initiative as the engine of growth; to encourage share ownership by Nigerian citizens in productive investments hitherto owned wholly or partially by the Nigerian Government and, in the process, to broaden and deepen the Nigerian market.

During the first phase of the exercise which spanned from July 1988 and June 1993, the following programmes were executed: 36 enterprises were privatised through public offer of their shares; 4 enterprises were privatised on Deferred Public Offer method; 8 enterprises were privatised via Private Placement method; 8 enterprises were privatised via Sale of Assets method; 1 enterprise was privatised through Management Buy Out method (MBO). Sale of non-water assets of about 18 River Basin Development Authorities. ${ }^{80}$

Under the Phase I programme, about 88 public enterprises were either fully or partially privatised. These were enterprises in which the Nigerian Government invested jointly with foreign or private Nigerian investors. With the exception of the Cement and the Oil Marketing companies, the capitalisation of most of them was small. The huge capital-intensive and basic industries like the Fertiliser Companies, Sugar companies, Vehicle Assembly Plants, Paper and the Steel Mills which hold vital positions in the economy could not be privatised for various reasons ranging from financial insolvency to negative networth. Finally, there was lack of clarity of Government's policy on some critical issues associated with the implimentation of the programme. $^{81}$

6. Reasons Why Governments Embark on Privatization: The Factors Worldwide

The reasons why government embark on privatization will be later captured under two sub-heads for the purpose of this paper otherwise there could be more and there are: poor performance of state owned enterprises and political interferences.

The period around 1970s was characterized by the multiplication of public enterprises in majority of the developing countries, mainly because of the thought that they cover the strategic sectors. $^{82}$ But even during that period, public enterprises proliferated in sectors that could

\footnotetext{
${ }^{77}$ Anya O. Anya, above note 6.

${ }^{78}$ Ibid.

${ }^{79}$ In March 1988, the then Nigerian Head of State, Ibrahim Badamosi Babangida promulgated a decree establishing the Technical Committee on Privatisation and Commercialization (TCPC). The committee was formally inaugurated in July 1988 to undertake the task of reform of public enterprises, as an integral and critical component of the Structural Adjustment Programme (SAP), which was started in 1986.

${ }^{80}$ Ibid.

${ }^{81}$ Ibid.

${ }^{82}$ State owned enterprises were widely promoted during the 1960s and 1970s on the basis of following principal premises.: -Such enterprises encouraged broad social responsibility and responsiveness to the public interest, SOEs helped to create stable investment and employment partners, SOEs provides models for improved industrial relations, SOEs could beneficially replace private natural monopolies, producing higher output at lower prices,
} 
scarcely be called strategic. Examples of such service activities (e.g. marketing and exporting offices, tourism, hotels and catering, financial services, etc.) arid to a lesser extent small and medium industrial enterprises. This expansion of the public sector in all directions is evidence of the growing role of the state within the different types of mixed; economy in the developing countries which resulted in the most heterogeneous public appropriations in the late 1970s. It made a reaction in favour of the private sphere in the form of privatization virtually inevitable.

Moreover, public enterprises often need to keep afloat at the taxpayer's expense, either through explicit governmental subsidies, such as direct cash grants, or through implicit subsidies, such as subsidized credit, guaranteed sales to the government at the fixed prices, reductions of tax liabilities, governmental injections of equity, or preferential exchange rates ${ }^{83}$. Finally, because of the burden of the SOEs, some authors argue that the state has failed to implement appropriate economic and social policies. ${ }^{84}$

Each country has different social, political and economic circumstances. Therefore, the reasons for privatization and the decline of nationalization activity vary from country to country and even from one enterprise to another. Generally, however, privatization programme worldwide has been driven by both political ideology and pragmatism. Although there are many considerations, privatisation was largely a reaction to the shortcomings of the public enterprise sector and the failure of previous attempts to exercise effective parliamentary control of their management and operations. Privatization was expected to result in increased efficiency and better management. In addition, the proceeds from privatization met a rising share of Governments' revenue needs, and helped to finance tax cuts ${ }^{85}$.

The following reasons can be considered the most common facts of the privatization trend in the international arena:

(a) Disappointing Performance of State Owned Enterprises

State Owned Enterprises (SOEs) have generally posted disappointing performances. ${ }^{86}$

With the utilities as a favourite example, SOEs provided irreplaceable means of direction and control in defencerelated industry, SOEs could successfully stimulate sectoral competition, SOEs were potent instruments of decolonization, given the desire of nationalist political elites to radically reduce foreign corporate ownership within the private sector.

${ }^{83}$ According to Shirley: "The economic problems that arise when bureaucrats are in business; that is, when governments own and operate enterprises that could be run as private firms...bureaucrats typically perform poorly in business, not because they are incompetent... but because they face contradictory goals and perverse incentives that can distract and discourage even very able and dedicated public servants. See also, Mary M. Shirley, "Getting Bureaucrats Out of Business: Obstacles to State Enterprise Reform", web page] of Center for International Private Enterprise, available online at http//www.dpe,org/ accessed 13 October, 2013.

${ }^{84}$ In economic terms, state failure means supplying a country with public goods that are too highly priced and too low in quality-in both cases for structural reasons. In political terms, state failure means a chronic inability to take decisions widely agreed to be necessary-again for deep-seated reasons. (Martin Janicke, State failure-The Impotence of Politics in Industrial Society, Translated by: Alan Braley, Polity Press, Cambridge \& Oxford, 1990, p. 8.

${ }^{85}$ For example, in other words, in the United Kingdom, as in many other countries, the political pressure for privatisation, came from a combination of disillusionment with the result of state ownership and from a belief that private ownership would bring substantial economic benefits, State-owned industries were viewed as highly Inefficient, slow at developing by introducing new technologies, subject to over-frequent and damaging political intervention and dominated by powerful trade unions. Privatization seemed to offer a means of ridding the state of the financial burden of loss making activities, while at the same time spreading share ownership 'and curtailing union power. Moreover, privatization sales offered a tempting source of state funding at a time when economic policy was geared to reducing the public sector- borrowing Requirement. According to Graham background factors in British privatisation programme are as follows: (a) The neo-liberal ideals of Conservative Party and Margaret Thatcher, (b) The aim of cutting back the public expenditure and in that context cutting back the public sector borrowing requirement (PSBR), (c) The financial difficulties of nationalized industries. (Cosmo Graham, "Privatisation-The United Kingdom Experience", Brooklyn Journal of International Law, Volume XXI, 1995, Number 1, p. 190, 191).

${ }^{86}$ See Michael I. Obadan, The Economic and Social Impact of Privatisation of State-owned Enterprises, African Books Collective, 2008, Chapter 5. 
Although some of the SOEs function well, ${ }^{87}$ many others are considered notoriously inefficient. Most SOEs in most developing countries have suffered severe and sustained losses. They manage to survive through tariff protection against competing imports, preferences in public procurement, exclusive rights, and preferential access to credit, governmental guarantees, tax exemptions, and public subsidies. The chronic losses incurred by state-owned enterprises often force governments to borrow money to cover them. These measures lead to high inflation, which discourages investment and causes capital flight.

For example in Nigeria, before the divestment exercises of the 1980s, the financial involvement of the Federal Government of Nigeria in industrial and commercial enterprises was about N23.2 billion naira. This was made up of N11.4 billion naira in equity and N11.8billion as loans and guarantees. Besides, government grants and subventions to these public enterprises were estimated at N11.5 billion naira. These investment statistics will only make much meaning if they are examined against the backdrop of the performance of these public enterprises, particularly in terms of their return on investment.

There is no gain-saying it that over the years, successive government have decried the inefficiency and poor performance of most public enterprises. The setting up of many special panels from the 1960s to look into various aspects of all or specified public enterprises bears eloquent testimony to this unsatisfactory performance. For example, the 1981 Presidential Commission on Parastatals (Onosode Commission) ${ }^{88}$ revealed in its report that public enterprises in Nigeria had critical problems relating to; defective capital structures resulting in heavy reliance on the national treasury for financial operations; mismanagement of funds and operations; corruption; misuse of monopoly powers; and bureaucratic bottlenecks within Public Enterprises, on the one hand, and between them and their supervising Ministries, on the other.

(b) Political interference

State Owned Enterprises (SOEs) are also thought to serve political objectives or purposes, and consequently, suffer frequent interference by government and bureaucrats. ${ }^{89}$ In some countries, they have also contributed to income redistribution in favour of the relatively well-off, over the poor, who generally lack access to both the jobs the-SOEs provide and their products.

Also political interference in the enterprise results in excessive employment, poor choices of product and location, lack of investments and ill-defined incentives for managers). While Public Enterprises are more susceptible to pressure from interest groups, private firms are able to focus solely on maximising profits.

The poor performance of the Public Enterprises that existed before 1970 was attributed to the poor nature of management especially with respect to the process of selection, appointment, promotion, incentive and discipline in the leadership hierarchy. ${ }^{90}$ In Nigeria, the problem seems to be a post-independence development.

\section{Conclusions}

\footnotetext{
${ }^{87}$ The performance of some state-owned enterprise-for example, in Malaysia and France-has been excellent. (Paul \$tarr/meaning,html). In France, in Renault and EOF (an electrical heating company) the performance was very good. (Jean-Pierre C. Anastassopoulos, "The French Experience: Conflicts with Government”, State-Owned Enterprise in the Western Economies, Edited By: Raymond Vernon and Yair Aharani, Croom Helm Ltd., 1981, p.111). Similarly, the most efficient steel company in the world, is the Korean Posco (Pohang Steel Company) which is state owned.

${ }^{88}$ Federal Republic of Nigeria, Report of the Presidential Commission on Parastatals (under the Chairmanship of G.O. Onosode) $24^{\text {th }}$ October, 1981.

${ }^{89}$ B.O. Oshionebo, "Public Enterprises Performances and Management in Nigeria: An overview" at the Seminar on Public Enterprises Reforms, NCEMA, Ibadan, Nigeria, June 5-16, 2000, p.79. See also, M.I Obadan above note 86 , at p. $46-47$.

${ }^{90}$ Ibid.
} 
This research have shown that the concept of privatization is an old but noble idea that governments have adopted to secure the continued existence of public utilities or state enterprises which ordinarily would have gone underground because of poor performances by selling existing shares to individuals and private corporations. It is observed after the disintegration or collapse of the Union Soviet Socialist Republic (USSR) in the early 90s, ${ }^{91}$ there is hardly any country in the world that have not adopted one form of privatization or another in other to bailout ailing state infrastructure or to meet with the socio-economic and political promises to the citizens. Though the process of privatization is sometimes cumbersome as government will have to put in place necessary legislation to set the ball of privatization rolling, most times the goals set out are achieved after several years would have gone and its is sometimes an on-going process in the political life wire of a country. This argument could be buttressed by the experience of Nigerian nation that is still in the process of privatization after the idea was introduced in 1988 by the Ibrahim Babangida's administration; in 2013, after more than 13 years, the government of President Goodluck Jonathan has struggled to privatise the Power sector in Nigeria as part of its economic reform policies. ${ }^{92}$ It is also observed that apart from poor performances, political interferences constitute a major reason why nations embark on privatization drive and the benefits accruable from the idea of privsatisation of public enterprises in Nigeria include but not limited to: curbing corruption, promote operational efficiency and effectiveness through better corporate governance; generate employment through private sector driven expansion; cut down on public debt and control public spending; to develop the capital market, increase the stakes of individual citizens in public enterprises through share ownership and encourage activities in other sectors of the economy. ${ }^{93}$

\footnotetext{
${ }^{91}$ In December of 1991, the Soviet Union disintegrated into fifteen separate countries. Its collapse was hailed by the west as a victory for freedom, a triumph of democracy over totalitarianism, and evidence of the superiority of capitalism over socialism. Gorbachev conceded power, realizing that he could no longer contain the power of the population. On December 25, 1991, he resigned. By January of 1992, by popular demand, the Soviet Union ceased to exist. In its place, a new entity was formed. It was called the "Commonwealth of Independent Republics," and was composed of most of the independent countries of the former Soviet Union. "The Cold War Museum: Fall of the Soviet Union", available online at http://www.coldwar.org/articles/90s/fall_of_the_soviet_union.asp, accessed 24 October, 2013.

${ }^{92}$ Clara Nwachukwu, "Nigeria Realised N400bn from Electricity Privatisation" Vanguard Newspaper 3 September, 2013. The Technical Committee of the National Council on Privatisation, NCP. The Council just concluded the largest privatisation transaction in Nigeria's history with the sale of 15 power companies unbundled from the Power Holding Company of Nigeria, PHCN, to private investors. the number of PHCN Successor Companies. There are 11 Distribution Companies (Discos) and seven Generation Companies (Gencos) and then there is the Transmission Company of Nigeria (TCN), available online at http://www.vanguardngr.com/2013/09/nigeria-realised-n400bn-from-electricityprivatisation/\#sthash.pUqfYgQR.dpuf, accessed 27 October, 2013.

${ }^{93}$ Kudus Adebayo, above note 67, at p.7.
} 